\title{
Ressenya de: Jordi A. López Lillo (2019) La política salvaje. Una teoría genealógica de los fundamentos sociales. Oxford. BAR Publishing.
}

\author{
Clemente Penalva (Universitat d'Alacant, Alacant, Espanya)
}

Cita bibliogràfica: Penalva-Verdú, C. (2021). Ressenya de: Jordi A. López Lillo (2019) La política salvaje. Una teoría genealógica de los fundamentos sociales. Oxford. BAR Publishing. Disjuntiva, 2(2), 101-104. https://doi.org/10.14198/DISJUNTIVA2021.2.2.6

La naturalització és un procés a través del qual els individus arriben a considerar algunes construccions socioculturals com a coses naturals, és a dir, donades, originals, que no han patit cap tipus de transformació. Aquest procés té una importància vital per a la percepció del món i per al comportament i l'acció col-lectiva. Hui dia sorprèn com algunes institucions, com són l'Estat o el Mercat, han arribat a naturalitzar-se de tal manera que molta gent no pot pensar en la societat -i en la història de les societats- sense col-locar a aquestes institucions com a vectors impulsors de la seua formació. Les societats sense Estat són considerades endarrerides, primitives, no civilitzades, salvatges. Aquesta concepció també està present -i contribueix enormement a aquest procés de naturalització- en el pensament acadèmic. Els treballs de recerca que donen llum sobre aquestes nocions són necessaris i molt útils per fer veure, per exemple, que les societats salvatges i les contemporànies no es diferencien substancialment. La política salvatge no difereix en essència de la contemporània; ocorre que es transforma o apareix amb diferents formes segons diferents cultures.

Una investigació el principi de la qual era establir un marc teòric que poguera servir d’ajuda a l'anàlisi arqueològica i a interpretar els objectes culturals materials, desemboca en una profunda i extensa reflexió sobre les principals categories que fan servir les ciències socials per estudiar la vida humana. Suposa un exercici metodològic molt poc freqüent en el treball científic: un salt consistent en començar avaluant unes ferramentes que ajuden a accedir a un objecte d'estudi per a acabar analitzant aquestes mateixes eines, convertint-les en l'objecte d'estudi. Poques investigacions que permeten obtenir un títol, com és el cas d'una tesi doctoral, realitzen aquest extraordinari esforç i adopten aquesta actitud tan valent. Aquesta és la feina de Jordi A. López Lillo (investigador de formació històrica i arqueològica duta a terme a la Universitat d'Alacant i a la Universitat Nacional de Còrdova -Argentina- que ha participat en diferents investigacions arqueològiques a Europa i Amèrica i que a la actualitat és investigador de l'CSIC) amb el títol La política Salvage; Una teoría genealógica de los fundamentos sociales, publicat per BAR Publishing. El transcurs de l'exposició de la seua investigació condueix a una sèrie preguntes que potser no es resolen completament, com reconeix el mateix autor. Però l'impressionant recorregut de les concepcions antropològiques, sociològiques, econòmiques i filosòfiques desenvolupades en els darrers dos segles -amb les seues fonts clàssiques- i la seua articulació en una sèrie de capítols estructurats que condueixen a una difícil lectura unidireccional (es fan necessàries relectures cap al darrere per seguir avançant en les argumentacions i les seues fonts, com el mateix autor suggereix mitjançant referències a diferents apartats), ofereix l'oportunitat d'aprendre, i convida a qui ho llegeix a participar en les reflexions i en la formulació de noves preguntes rellevants per conèixer les formes de relacionar-se els éssers humans.

Clemente Penalva-Verdú.Correu electrònic de correspondència: clemente.penalva@ua.es https://orcid.org/0000-0002-5408-388X 
El llibre és un constant anar i vindre entre les esferes de la vida social que la cultura occidental ha anat compartimentant com a entitats separades: l'economia i la política. L'exercici de connectar-les resulta molt productiu, perquè fa saltar a la vista elements concrets que les investigacions de camp han establert com a vincles entre els dos espais: rituals, parentiu, suport i consum, normes, fonts d'autoritat i llei, i un llarg etcètera. En la lectura del text, molt poques categories bàsiques sobre la conducta humana es mostren assentades. La majoria són discutides i, en molts casos, rebatudes per la sospita que són producte de la mirada occidental, que és una mirada etnocèntrica i evolucionista (una espècie de mirall on el "civilitzat" es construeix reflexivament en el temps i l'espai) que ha conduït a separar el salvatge del civilitzat per legitimar el sistema de dominació occidental i la depredació de la naturalesa i els seus efectes que ens ha dut a la actual crisi multidimensional del sistema capitalista. Per això, com assenyala l'autor a l'inici, algunes de les categories de les que parteixen les disciplines socials poden constituir-se en traves per explorar l'estudi de la política i l'econòmic. L'autor, concebent aquestes esferes com a institucions culturals del social, arriba a observar el sorgiment de l'Estat com una cosa accidental i no com a fruit d'una evolució lineal de el desenvolupament. El recurs a considerar les "condicions de possibilitat" (dels discursos -Foucault- o de les pràctiques -Bourdieu) per al seu sorgiment, es fa tan necessari com complex, tenint en compte, a més, que el treball antropològic s'ha realitzat en un món que és històric i en qual totes les societats i cultures preindustrials i industrials estan en contacte des de que va començar el procés de colonització que va acompanyar al desenvolupament de la modernitat.

Encara que la seua presència a l'obra no és tan freqüent com altres autors (Sahlins, Bourdieu, Graeber, per exemple), en el desenvolupament de l'exposició subjau el treball de l'antropòleg francès Pierre Clastres, que concep les societats primitives com societats contra l'Estat. Unes societats d'abundància -i no de escassesa- que es prevenen, mitjançant la guerra, de la centralització del poder i la diferenciació social. La guerra -no confondre amb estructura militar industrial dels Estats moderns- com a estructura cultural permet identificar la societat com un tot -identificant la frontera identitària de el nosaltres comunitari i l'altre- i evita l'emergència de l'Estat per l'efecte d'impossibilitar la unificació de unitats disperses. Així, fent un repàs intensiu de la literatura antropològica i sociològica que intenten donar explicació a les formes de convivència humanes, l'autor atén les dinàmiques de estatització i contraestatització que contextualitzen les anàlisis arqueològics.

No deixa de ser una proposta agosarada perquè suposa observar, en l'econòmic, les formes d'intercanvi, la importància del context ecològic i la focalització de les estructures socials i polítiques fonamentades tant en la producció com en el consum. Pel que fa a la política, poder, autoritat, sobirania, llei són les categories que impulsen la investigació teòrica que presenta l'autor.

L'obra està dividida en dues parts amb cinc capítols cadascuna. En la primera es realitza una genealogia de l'economia i en la segona una genealogia de la política. Aquests dos grans blocs estan flanquejats per una introducció i una conclusió. En la introducció es planteja l'objecte de la investigació. L'autor aborda les diferents concepcions i teories antropològiques sobre un dels seus objectes (les determinacions culturals de la percepció de la política i els seus efectes pràctics) i les fronteres entre el cultural i el natural, defineix la cultura com trames de significació i ho exemplifica amb una interessant aproximació a la manera que tenen diferents cultures de percebre el nombre de vocals sobre un mateix aparell fonològic que comparteixen tots els membres de l'espècie humana. En la conclusió és on s'ofereix -com indica el subtítol de l'obra- una "teoria genealògica sobre els fonaments socials".

En la primera part, el lector o la lectora pot trobar els fonaments i les discussions sobre el concepte d'"economia domèstica" i, així, circumscriure un conjunt de categories econòmiques en el marc de les concepcions duals que expliquen la coexistència de formes de treball i intercanvi pre i capitalistes i que l'autor enllaça amb el binomi sociològic comunitat / societat. Tots dos esquemes donen peu a situar els rellevants estudis del rus Chayanov, que van abordar les lògiques econòmiques camperoles. Rellevants perquè, al presentar un contrapunt a l'economia clàssica introduint el valor subjectiu de les mercaderies, qüestionen els pressupostos centrals de l'economia formal: la producció i la racionalitat econòmica. És aquí, connectant-lo amb Chayànov, on l'autor comença a introduir a Scott, Polanyi i Bourdieu, autors que, incorporant els valors, la seguretat i el sentit igualitari a l'hora de garantir el suport -col-locant el consum com a element central- assenyalen la concepció originària moral de l'economia i possibiliten entendre la concepció cultural de les pràctiques econòmiques, que és el fonament de l'anomenada economia substantiva. Continuant amb aquest principi "moral" de l'economia les arrels del qual ja estan en el pensament econòmic d'Aristòtil tracta, en següents apartats i capítols, el tema de l'intercanvi i els diners. La coneguda concepció de Marx sobre els tipus de circulació mercantilista (M-D-M' i D-M-D') permet una primera connexió d’allò econòmic amb allò polític, el poder i l'autoritat. La primera circulació no pot mesurar amb precisió l'intercanvi perquè està regida pel valor d'ús, la finalitat és el consum; mentre la segona -que és el principi de l'acumulació capitalista- potencia la jerarquització social, tot i que indica l'autor que en termes societals -i polítics- segueix subjacent el valor d'ús de la primera circulació. Un procés, explicita l'autor, de "fusióconfusió" d'aquestes dues circulacions on la segona, realment, el que fa és incrementar la potència de la primera. Tenir més diners suposa tenir més capacitat de mostrar riquesa i poder. Fusió/confusió que s'il·lustra amb el camí de l'arrel 
etimològica que comparteixen els dos termes: la mateixa arrel "ric" és primera com "rei" -regi- i posteriorment com "ric". Un poder que utilitza els diners -i la capacitat de consum derivada- com a signe. Segur que és una excessiva simplificació sintetitzar aquests extensos i complexos capítols en què es tracta el valor, els diners, l'intercanvi, l'excedent i el mercat, dient que l'autor ens pretén mostrar que el fet que les lògiques d'intercanvi (mercaderies, treball, serveis) que mostra la primera circulació són les més freqüents, fins i tot en l'economia capitalista, i que no estan distants de les economies domèstiques i comunitàries que analitza, entre d'altres, Chayànov. El que passa és que aquestes lògiques coexisteixen amb les de l'economia orientada al guany i la extracció de valor de canvi capitalista. I, el més important, que són els processos de significació culturals, mediats, òbviament, per la ideologia els que ha provocat una confusió en l'anàlisi de les situacions i pràctiques de la quotidianitat domèstica que tendeixen a observar-se monetaritzades i comptables.

El càlcul quantitatiu no sempre està present, i aquí resulta molt útil la teoria de les pràctiques de Bourdieu. Assumint el context sociocultural que envolten les pràctiques econòmiques, una part de la literatura antropològica econòmica mostra com el càlcul en les relacions d'intercanvi posa en risc la comunitat. Són les experiències d'èxit en les pràctiques realitzades les que incorporen una racionalitat social que no és igual a la que cerca el guany o la utilitat (la racionalitat en l'elecció dels mitjans per aconseguir una fi, de la qual parla l'economia formal). No obstant, i per tal de superar el debat entre economia formal i substantiva (aquesta última sosté que les eleccions estan intervingudes per institucions culturals i polítiques que poden perfectament orientar la producció de forma col-lectiva o establir un intercanvi basat en la reciprocitat o la redistribució ), la proposta de l'alacantí és deixar en suspens el problema de la producció i de l'escassesa per seguir endinsant-se -i així superar el debat entre aquestes dues perspectives- en l'estudi del consum. L'estudi de l'economia centrada en el consum, d'altra banda, resulta necessari per a relativitzar les concepcions materialistes -Marvin Harris seria el representant més conegut- que en síntesi podríem dir que expliquen les relacions humanes i la conducta -la econòmica i la política- determinada, en última instància, per les condicions d'existència objectivades en els recursos disponibles en un entorn ecològic específic. Les adaptacions culturals a l'entorn natural són tractades en aquest capítol, oferint una teoria de la història de les societats molt diferent a la lineal evolucionista, aportant un model de fases sistòliques i diastòliques determinades per aquestes adaptacions, on diferents estratègies relacionades amb l'organització de el poder $\mathrm{i}$ les seues pràctiques econòmiques associades es confonen amb els discursos polítics. En aquest capítol, il·lustrant amb diferents investigacions antropològiques, s'aborden els circuits d'intercanvi del suport i del prestigi d'objectes, persones (esclaus) i de parents per fer notar com es connecten poder i identitat per a possibilitar la integració dels diferents cossos socials en desequilibri, en una lògica paradoxal. Una lògica que es fa més comprensible si s'atén a l'establiment de jerarquies sota el principi de "englobament del contrari" de Dumont i s'observa la coincidència etimològica dels termes "hoste" i "enemic". En tot cas, la gran variabilitat d'entitats que intervenen en els intercanvis fa obligada la idea d'assumir que els efectes socials d'aquestes pràctiques venen determinats no per la naturalesa del que s'intercanvia (el seu valor d'ús) sinó, més aviat, per seua capacitat de representar (jerarquia, identitat), al funcionar com a signes.

L'autor ens parla d'un conjunt de exterioritats dels diners que li permeten actuar simbòlicament en les relacions socials. Exterioritats com són la seua capacitat per significar posicions socials a través del consum -poder consumir és la capacitat de produir signes de distinció i identitat- o confiança -diners fiduciari- en la llei.

En aquest intricat viatge pels corrents antropològiques, tractant els fonaments de la vida econòmica i social -amb la inserció d'un apartat on s'exposa una interessant proposta de diferenciació entre poder, autoritat i dominació per arribar a l'element essencial de els diners-, l'autor va oferint més evidències de l'estreta relació entre economia i política, a l'extrem d'afirmar que economia és política. Prèviament, l'autor il-lustra la mutació de significat d'economia a través de la seua font original grega: oikonomia. El pas d'una concepció ancorada en el domèstic (oikonomia no es refereix a l'individu en termes smithians com propensió a l'intercanvi, sinó que cal contextualitzar-la en la lògica de proveir les necessitats concretes i culturals del consum domèstic, segons una lògica comunitària tal com la considerava el cos polític ciutadà) al seu significat actual, vinculat al mercat. En una lògica comunitària hi ha una lògica "política" de justícia pel que fa a l'establiment d'un "preu just", però quan s'estén l'intercanvi la crematística muta (de gestionar i adquirir valors d'ús a l'activitat centrada a adquirir valors de canvi com fi en si mateixa) desenganxant l'esfera privada de la comunitària, o el que és el mateix, despolititzant l'economia i posant les bases per a un posterior ús generalitzat de la moneda. De la mutació, i la seua adaptació exitosa que permet la replicació d'aquestes pràctiques econòmiques, apareix una nova forma de enriquir-se a través del comerç, i unes noves formes de relacionar-se i d'accedir a l'autoritat del poder econòmic.

Si a la primera part del llibre es realitza una mena d'arqueologia de l'econòmic, la segona aborda una arqueologia de la política. S'aborden les lògiques subjacents en l'emergència de l'Estat, refermant la idea que economia i mercat convergeixen en l'ordenació de l'espai polític. Un conjunt d'investigacions antropològiques (els estats de gràcia dels "Talladors de caps", la "Fama de Soga" o els "Cultes cargo") mostren en els capítols 6 i 7 els processos d'adquisició de prestigi i prefectura mitjançant accions bèl-liques i rituals que inclouen algun tipus de circulació de béns. Uns processos en els quals està present la mimesi colonial i que serveixen per explicar l'origen de l'Estat (o de l'estatització), no com 
evolució de les formes d'organització prèvies al seu sorgiment; sinó a través de processos d'integració de les societats colonitzades en els estats colonials, o com a processos de ruptura de l'estabilitat davant les situacions de desintegració de la vida social provocada precisament per l'acció colonitzadora. Es tracta de la primera aproximació del llibre a la proposta teòrica que l'Estat sorgeix com a excepció, com a necessitat de reequilibri. Un reequilibri que es produeix no tant per l'acció política com per la reestructuració del conjunt de creences sobrenaturals que tenen el seu fonament en les íntimes relacions entre identitat i política (la integració de l'altre implica establir una relació jeràrquica segons l'esquema de l'englobament del contrari a la que ja s'ha fet referència). D'alguna manera, la colonització i la incursió política a través de la religió produeixen efectes en l'ordre polític dels grups indígenes, com queda exemplificat en les estratègies de la colònia per al reconeixement de líders locals. Un procés de mimesi i d'assimilació en les seues pròpies tradicions religioses -i l'ordre polític que aquestes legitimen- a les dels colonitzadors, o un procés en el qual directament incorporen els colonitzadors a la seua cosmovisió com ancestres, obtenint evidència empírica de l'acció de el sobrenatural en el natural. L'acció colonial suspèn el poder transcendental indígena, fent que la situació excepcional es prolongue i, amb això, que la situació política es mantinga estàtica -en el sentit d'estancar una cosa que és fluïda-. És a dir, es torne Estat. Potser, aquí, està la clau de la proposta de l'autor per ajudar a entendre aquesta accidentalitat de l'Estat. L'excepcionalitat talla el flux, com deia Clastres d'una lògica "centrífuga de la parcel-lació, la dispersió, l'escissió, de manera que cada comunitat necessita, per pensar-se com a tal (com totalitat una) la figura oposada de l'estranger o de l'enemic" humà (afegim aquí), perquè els exemples etnogràfics esmentats parlen d'una identificació del colonitzador amb el sobrenatural. L'estatització sorgeix no per una competència política interna dels subjectes de la comunitat, sinó per la interposició d'institucions que interrompen aquest fluid i aquest ordre de coses (prestigi, prefectura, ritus, circulació de béns). Un procés en el qual la sobirania, diguem-ne, extranatural (entesa com a font de l'autoritat legítima perquè són suport de les accions humanes) que estava codificada en una sèrie de mites i de creences sustentades en la separació entre allò natural (i humà) i allò sobrenatural, queda trastocada per la novetat de fer-se tangible el segon.

En els capítols finals, l'autor recupera d'alguns conceptes relatius a les formes de dominació del sociòleg alemany Max Weber i altres instruments analítics per a, mitjançant un exercici d'arqueologia jurídica, ampliar els arguments de la seua proposta teòrica sobre els fonaments i funcionaments socials de les institucions polítiques i, fins i tot, de la Història. Descartada la idea de sorgiment de l'Estat per evolució o per l'acció conscient dels actors socials, es completa la hipòtesi, ja suggerida en capítols anteriors, que el sorgiment de l'Estat és accidental. El seu origen es deu al fet que mutacions en les pràctiques -determinades per una tradició no estatista- reequilibren la reproducció dels grups humans en situacions d'excepcionalitat provocades per grans alteracions mediambientals. "Cataclismes" que afecten l'ordre social i que són semblants, des del punt de vista dels efectes, al provocat per les invasions colonials. Una situació d'excepcionalitat, recordem, que es perllonga en el temps, mantenint i enfortint la seua estructura. Per aprofundir sobre aquestes mutacions en les pràctiques, les seues dinàmiques i les seues significacions culturals, l'autor desenvolupa uns capítols en què s'obrin interessants debats sobre les dialèctiques entre legalitat i legitimitat, comandament i obediència, que sumades a les seues anàlisis genealògics del Dret i la llei, contribueixen a l'explicació general de l'obra i a ampliar algunes problemàtiques expressades en capítols precedents (el binomi autoritat-poder, per exemple) tornant sobre Foucault, Agamben i Bourdieu. El capítol final s'entén com la contribució teòrica de l'autor, presentant una teoria sobre els processos de estatització des d'una perspectiva que adopta la polisèmica expressió de "Perihistoria". Una perihistoria de les "societats sense història" de Clastres i una perihistoria des dels marges acadèmics de la Història com a disciplina, que està travessada, també, pels discursos de la dominació. En aquesta exposició es mostren gràficament els diferents "moviments" en la percepció dels espais de la natura i la cultura, ja siguin en un escenari contraestatista o en un estatista, i es fan referències als epígrafs anteriors de l'obra on es desenvolupen els conceptes i arguments exposats. 